\title{
An Experimental Study on Properties of Fly Ash Bricks
}

\author{
Rinku Kumar
}

\begin{abstract}
In fast growing today's world development of new building materials and Processing \& utilization of industrial waste is being given the top priority in the program of building research at a very high rate. This is important for achieving maximum disposal of wastes and conservation of scarce resources and materials.
\end{abstract}

The bricks produced were about $29 \%$ lighter than clay bricks. The compressive strength of bricks manufactured from fly ash possessed higher than $20 \mathrm{MPa}$. This generally exceeds the best of load carrying clay bricks available by more than $25 \%$ and is several times better than acceptable commercially available common clay bricks. Other important characteristics of the fly ash bricks have been evaluated. The values of these characteristics for fly ash bricks are excellent and have exceeded those pertaining to clay bricks. Moreover, fly ash bricks have been produced with a naturally occurring reddish colour similar to that of normal clay bricks. The new bricks and process have been patented. This dissertation presents the results of testing and the advantages gained by this type of fly ash bricks over conventional clay bricks.

In the present study, the effects of fly ash on the properties of bricks are studied and the behaviour of fly ash bricks is compared with conventional burnt clay bricks.

The various properties of fly ash bricks with different materials were tested. The properties studied water absorption, hardness, efflorescence, soundness, shape and size, crushing strength and basic compressive strength of the prism using different mortar mixes normally 1: 3, 1: 4 and $1: 5$ cement-sand mortars.

In general bricks are made by top fertile agricultural soil but by using fly ash, 28 percent of top fertile agricultural soil is saved. Use of fly ash in brick making also is beneficial in diverse ways. As compared to conventional clay bricks fly ash bricks are stronger, more durable and yet more economical. Also, the process of fly ash brick manufacturing results in lesser pollution. Being less permeable as compared to clay bricks dampness related issues are far lesser in case of fly ash bricks than their clayey counterparts.

Keywords - Conventional Bricks, Fertile agriculture soil, crushing strength of bricks, efflorescence, fly ash.

\section{INTRODUCTION}

Burnt clay bricks are being used extensively almost throughout India and are perhaps the most important building construction material. But the unlimited use of clay is harmful to society as all the bricks kilns in India depend on good quality clay available from agricultural fields and presuming a weight of $3 \mathrm{~kg}$. per brick. The total clay taken out from the agricultural fields per day was over 300 million tonnes for 10,000 Crore bricks. Moreover, clay bricks available in certain regions are poor in quality and costly which have forced engineers to look

Rinku Kumar, Assistant Professor, RPIIT, Technical Campus, Kurukshetra University, Kurukshetra, India for better material capable of reducing the cost of construction. At present, India has production capabilities of over 10,000 Crore bricks through around 45,000 local kilns (bhattas), in the unorganized sector. So the use of industrial waste products such as fly ash, for making bricks is ecologically and economically advantageous since apart from saving precious top agricultural soil, it meets the social objective of disposing industrial waste i.e. fly ash which otherwise is a pollutant and a nuisance.

The ever increasing volume of fly ash quantities in the world has not been remotely matched by its utilization. Australia is an example where such utilization has been minimal. The most important and popular use of fly ash in Australia has been in the partial replacement of portland cement. The use of fly ash in concrete is to the extent of maximum of $25 \%$ replacement of Portland cement. This conservatism can be understood in the context of concrete where the ash is mixed raw, and the effects of high volume replacement are still subject to research. It is however not quite justifiable that the brick industry should take similar conservative attitude. Environmental concerns have been raised in some parts of the world where coal is the main power generating resource and where bricks are also the main building material. Such concerns have resulted in legislation to oblige the brick industry to incorporate at least $25 \%$ by weight of fly ash and or bottom or pond ash in the brick making mixture if the industry is within $50 \mathrm{~km}$ from a coal power generation plant. Some successful ventures have been reported where fly ash was incorporated in the mixture at the rate of $20 \%$ to $50 \%$. Nevertheless, there is only little evidence that incorporation of fly ash in the brick mixture has exceeded the $30 \%$ by volume, even when the legislation was obeyed. Reasons behind such reluctance are not clear. A most probable reason is the fear of change in many small factories and the ingrained conservatism in the attitude of stake holders of the large producers. Added to this is the fact, that with an existing clay brick factory, the incorporation of fly ash is a potential addition of cost. The possible incompatibility of the ash with the clay and shale during the various processes of production including the crucial one of firing may be a legitimate difficulty.

At high temperatures beyond $1000{ }^{\circ} \mathrm{C}$, the temperature and length of time of firing become very sensitive to the type of ash and of course to the clay and shale if in the same mixture. This would be the case as long as the factory still uses the ash as partial replacement to the main clay and shale ingredients. The situation may become completely different when the ash is the only ingredient of the bricks mixture. Compatibility is no more an issue in such a case. So far, few attempts 


\begin{tabular}{|c|c|c|c|c|}
\hline \multicolumn{2}{|c|}{ 1.Normal Bricks: } \\
\hline S.No. & $\begin{array}{l}\text { Dry } \\
\text { Weight } \\
(\mathrm{kg})\end{array}$ & $\begin{array}{c}\text { Wet } \\
\text { weight } \\
(\mathrm{kg})\end{array}$ & $\begin{array}{c}\text { Water } \\
\text { absorption } \\
(\mathrm{gm})\end{array}$ & $\begin{array}{c}\text { Water } \\
\text { absorption } \\
(\mathrm{gm})\end{array}$ \\
\hline 1. & 3.13 & 3.50 & 370 & 10.57 \\
\hline 2. & 3.21 & 3.64 & 430 & 11.81 \\
\hline 3. & 2.78 & 3.21 & 430 & 13.40 \\
\hline \multicolumn{5}{|c|}{ Average } \\
\hline
\end{tabular}

Fig.1: Normal Water absorption Test

at manufacturing bricks from more than $80 \%$ fly ash have been made.

The engineers now believe that fly ash on its own can be an excellent raw material for brick making. This has now been proven and a patent is taken for the manufacture of bricks from fly ash.

The response of the ash to firing temperature at $1000{ }^{\circ} \mathrm{C}$ and beyond can be accurately controlled even in small factories. The potential savings with this approach are many. Savings in production and transportation costs and producing bricks of superior qualities to those of standard clay bricks are in addition to the environmental solution that such venture may bring about.

\section{OBJECTIVE AND SCOPE}

The objective of the present paper is to study the effect of fly ash bricks on the performance and the properties of bricks with the view to study the comparison between clay bricks and a fly ash brick because fly ash is enriched with silica, is the main constituent for conventional building material. From the experiment, it is further desired to compare the strength of fly ash brick by that of the conventional clay brick. The salient properties of bricks like crushing strength, water absorption, shape and size, soundness, hardness and efflorescence are to be determined.

Bricks will always be the necessity of building materials and in future soil for the making of bricks would not be available in plenty as the use of land is rapidly increasing, at that time fly ash will fulfil the necessity of clay bricks as these bricks are made by the industrial wastes. Moreover the building structures are getting heavier with time, the use of fly ash bricks would be more efficient as its strength is more than that of clay bricks.

\section{EXPERIMENTAL PROGRAMME}

In the present study, fly ash bricks are subjected to the following tests to find out its suitability for the construction work:

\section{A. Absorption Test:}

This test is carried out to determine the amount of water absorbed by the brick. When immersed in water for a period of 24 hours it should not, in any case, exceed $20 \%$ of weight of dry brick. This test is carried out for all the samples of fly ash bricks and clay bricks.

\begin{tabular}{|c|l|c|c|c|}
\hline \multicolumn{5}{|c|}{ 2. Fly Ash Bricks: } \\
\hline S.No. & $\begin{array}{l}\text { Dry } \\
\text { Weight } \\
(\mathrm{kg})\end{array}$ & $\begin{array}{c}\text { Wet weight } \\
(\mathrm{kg})\end{array}$ & $\begin{array}{c}\text { Water } \\
\text { absorpti } \\
\text { on }(\mathrm{gm})\end{array}$ & $\begin{array}{c}\text { Water } \\
\text { absorption } \\
(\mathrm{gm})\end{array}$ \\
\hline 1. & 3.17 & 3.47 & 300 & 8.64 \\
\hline 2. & 2.98 & 3.30 & 320 & 9.70 \\
\hline 3. & 3.00 & 3.37 & 320 & 10.97 \\
\hline \multicolumn{5}{|c|}{ Average } \\
\hline
\end{tabular}

Fig.2: Fly Ash Water absorption Test

\section{B. Hardness Test}

This test is carried out to see that the brick is sufficiently hard or not. We can judge hardness of the brick by maki ng impression on the surface of the brick with the help of a finger nail. This test is carried out for all samples of fly ash bricks and clay bricks.

\begin{tabular}{|c|c|}
\hline Normal Bricks & Fly Ash Bricks \\
\hline $\begin{array}{c}\text { No impression after } \\
\text { scratching with the help of a } \\
\text { finger nail. }\end{array}$ & $\begin{array}{c}\text { No impression after scratching on } \\
\text { the surface of brick. }\end{array}$ \\
\hline
\end{tabular}

\section{Efflorescence Test}

This test is conducted for finding out the presence of soluble salts in a brick when it is immersed in water for 24 hours and taken out and allowed to dry in shade. Absence of grey or white deposits on its surface indicates absence of soluble salts. If the white deposits cover about $10 \%$ surface, the efflorescence is said to be slight and it is considered as moderate, when the white deposits cover about $50 \%$ of surface. If grey or white deposits are found on more than $50 \%$ of surface, the efflorescence becomes heavy and it is treated as serious, when such deposits are converted into powdery mass. This test is carried out forth fly ash bricks and clay bricks.

\begin{tabular}{|c|c|}
\hline Normal Bricks & Fly Ash Bricks \\
\hline Slight to moderate & The grey deposit is less than $10 \%$ \\
\hline
\end{tabular}

\section{Soundness Test}

This sound is carried out to find out that a clear ringing sound is produced or not when the two bricks are struck with each other without breaking any of the two bricks.

\begin{tabular}{|c|c|c|c|c|c|}
\hline \multicolumn{6}{|c|}{ Fly Ash Bricks: } \\
\hline \multirow[t]{2}{*}{$\begin{array}{l}\dot{0} \\
\dot{Z} \\
\dot{n}\end{array}$} & 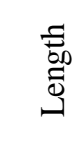 & 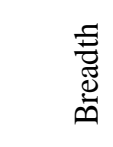 & 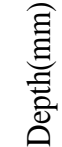 & 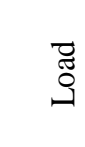 & 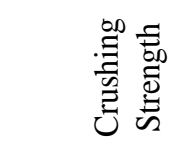 \\
\hline & $(\mathrm{mm})$ & $(\mathrm{mm})$ & & $\mathrm{KN}$ & $\left(\mathrm{N} / \mathrm{mm}^{2}\right)$ \\
\hline 1. & 228 & 114 & 75 & 387 & 14.89 \\
\hline 2. & 227 & 114 & 76 & 522 & 21.33 \\
\hline 3. & 228 & 113 & 74 & 390 & 15.13 \\
\hline 4. & 227 & 114 & 74 & 613 & 23.68 \\
\hline 5. & 227 & 114 & 74 & 453 & 17.50 \\
\hline \multirow[t]{2}{*}{6.} & 226 & 113 & 73 & 520 & 20.36 \\
\hline & & Average & & 18.81 & \\
\hline
\end{tabular}

Fig.3: Crushing Strength Fly ash 
If the two bricks are not broken after striking with each other and a clear ringing sound is produced then it means that the bricks are sufficiently sound. The procedure of this test is self explanatory.

\begin{tabular}{|c|c|}
\hline Normal Bricks & Fly Ash Bricks \\
\hline Good & $\begin{array}{c}\text { A clear ringing sound } \\
\text { produced }\end{array}$ \\
\hline
\end{tabular}

\section{E. Shape and Size Test}

This test is done to examine the structure of the brick when the brick is broken. It is seen that the structure of the brick is homogeneous, compact and free from any defects such as holes, lumps etc. or not. Mainly the defects such as holes, lumps should not be there.

\section{F. Crushing Strength Test}

This is the main test conducted to test the suitability of the brick for construction work. This test is executed with the help of compression testing machine.

A brick is placed in a compression testing machine. It is pressed till it breaks. Then the compression strength of the brick is recorded from meter of the compression testing machine. A brick after undergoing compression test, this test is carried out for both fly ash bricks and clay bricks.

\begin{tabular}{|c|c|c|c|c|c|}
\hline \multicolumn{6}{|c|}{ Normal Bricks: } \\
\hline \multirow[t]{2}{*}{$\begin{array}{l}\dot{0} \\
\dot{z} \\
\dot{s}\end{array}$} & $\begin{array}{l}\text { 퐁 } \\
00 \\
0 \\
.\end{array}$ & 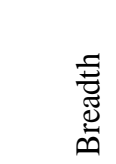 & 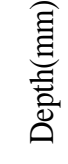 & 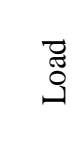 & 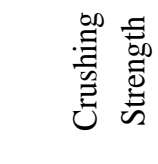 \\
\hline & $(\mathrm{mm})$ & $(\mathrm{mm})$ & & $\mathrm{KN}$ & $(\mathrm{N} / \mathrm{mm})$ \\
\hline 1. & 228 & 110 & 72 & 220 & 8.70 \\
\hline 2. & 221 & 110 & 70 & 160 & 6.58 \\
\hline 3. & 220 & 105 & 69 & 160 & 6.93 \\
\hline 4. & 218 & 104 & 70 & 220 & 9.70 \\
\hline 5. & 227 & 104 & 74 & 200 & 8.47 \\
\hline \multirow[t]{2}{*}{6.} & 226 & 103 & 71 & 190 & 8.47 \\
\hline & & Average & & 8.14 & \\
\hline
\end{tabular}

Fig.4: Crushing Strength Normal Brick

\section{G. Prism Test}

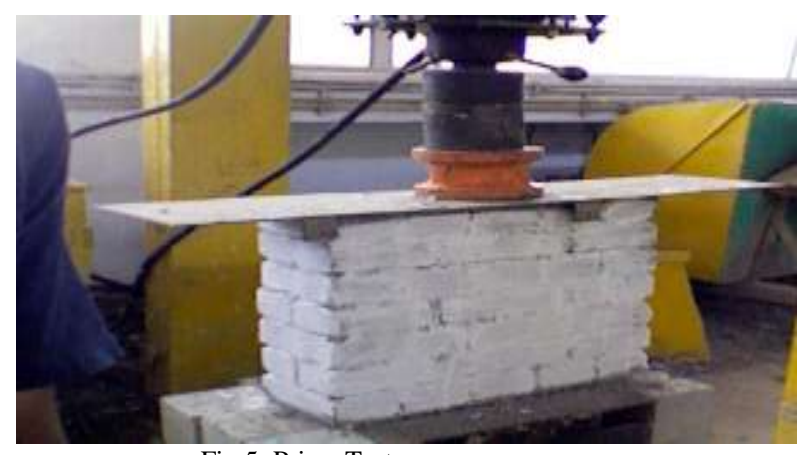

Fig.5: Prism Test

\begin{tabular}{|c|c|c|c|c|c|c|}
\hline 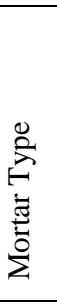 & $\begin{array}{l}\text { Prism } \\
\text { Size } \\
(\mathrm{mm}) \\
(\text { Width } \\
\times \text { thich } \times \\
\text { hight) }\end{array}$ & $\mathrm{h} / \mathrm{t}$ & 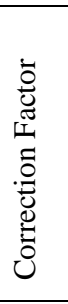 & 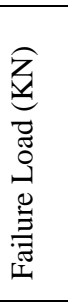 & $\begin{array}{l}\text { Basic } \\
\text { Compre } \\
\text { ssive } \\
\text { Stress of } \\
\text { Fly Ash } \\
\text { Bricks } \\
\text { Mpa }\end{array}$ & $\begin{array}{l}\text { Basic } \\
\text { Compressi } \\
\text { ve Stress } \\
\text { of Class A } \\
\text { Bricks As } \\
\text { Per IS: } \\
1905-198 \\
7 \mathrm{Mpa} \\
\end{array}$ \\
\hline $1: 3$ & $\begin{array}{c}600 \times 230 \\
\times 685\end{array}$ & 3 & 0.86 & 290 & 1.8 & 1.31 \\
\hline $1: 4$ & $\begin{array}{c}600 \times 230 \\
\times 610 \\
\end{array}$ & 2.65 & 0.82 & 264 & 1.56 & 1.19 \\
\hline $1: 5$ & $\begin{array}{c}600 \times 230 \\
\times 610\end{array}$ & 2.65 & 0.82 & 240 & 1.42 & 1.13 \\
\hline
\end{tabular}

IV. ANALYSIS OF RESULTS

A. Absorption Test

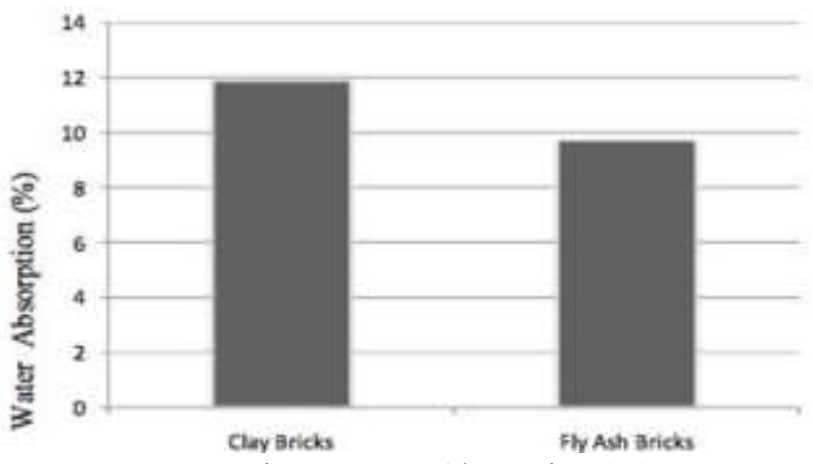

Fig. 7: Water Absorption (\%)

The average absorbed moisture content of clay bricks is found to be $11.93 \%$ and for fly ash bricks are found to be $9.77 \%$. Thus there is net $18.10 \%$ decrease in moisture absorbed for fly ash bricks as a part to clay bricks.

\section{B. Hardness Test}

The hardness test for clay bricks and fly ash bricks was conducted, test brick was taken and scratch was made on bricks surface with the help of finger nail and found no impression after scratching in both the cases.

\section{Efflorescence Test}

The Efflorescence test for clay bricks and fly ash bricks was conducted and the results were compared in which Grey or white deposits are slight to moderate in normal bricks and less than $10 \%$ on the surface area in fly ash bricks.

\section{Soundness Test}

The Soundness test for clay bricks and fly ash bricks was conducted and the results were compared in which two bricks are struck with each other, It was found that a normal brick shows good results when struck with each other but fly ash bricks show clear ringing sound. 


\section{E. Shape and Size Test}

The Shape and Size test is done for clay and fly ash bricks to examine the structure of a brick when the brick is broken and it was found both types of bricks are free from any defects such as holes, lumps etc. but fly ash bricks are compact and homogeneous.

\section{F. Crushing Strength Test}

Crushing strength test for clay bricks and fly ash bricks was conducted and the result are compared in Table: 4.2

\begin{tabular}{|c|c|c|}
\hline Type of Bricks & $\begin{array}{c}\text { Average Crushing } \\
\text { Strength } \\
(\mathrm{N} / \mathrm{mm})^{2}\end{array}$ & $\begin{array}{c}\text { \% Increase Average } \\
\text { Crushing Strength }\end{array}$ \\
\hline $\begin{array}{c}\text { Class A } \\
\text { Clay Bricks }\end{array}$ & 8.14 & --- \\
\hline Fly Ash Bricks & 18.81 & 56.72 \\
\hline
\end{tabular}

Fig. 8: Average crossing strength

The crushing strength of clay bricks is found to be $8.14 \mathrm{~N} / \mathrm{mm} 2$ and for fly ash bricks is found to be $18.81 \mathrm{~N} / \mathrm{mm} 2$. Thus there is net $56.72 \%$ increase is crushing strength for fly ash bricks as a part to clay bricks.

\section{G. Prism Test}
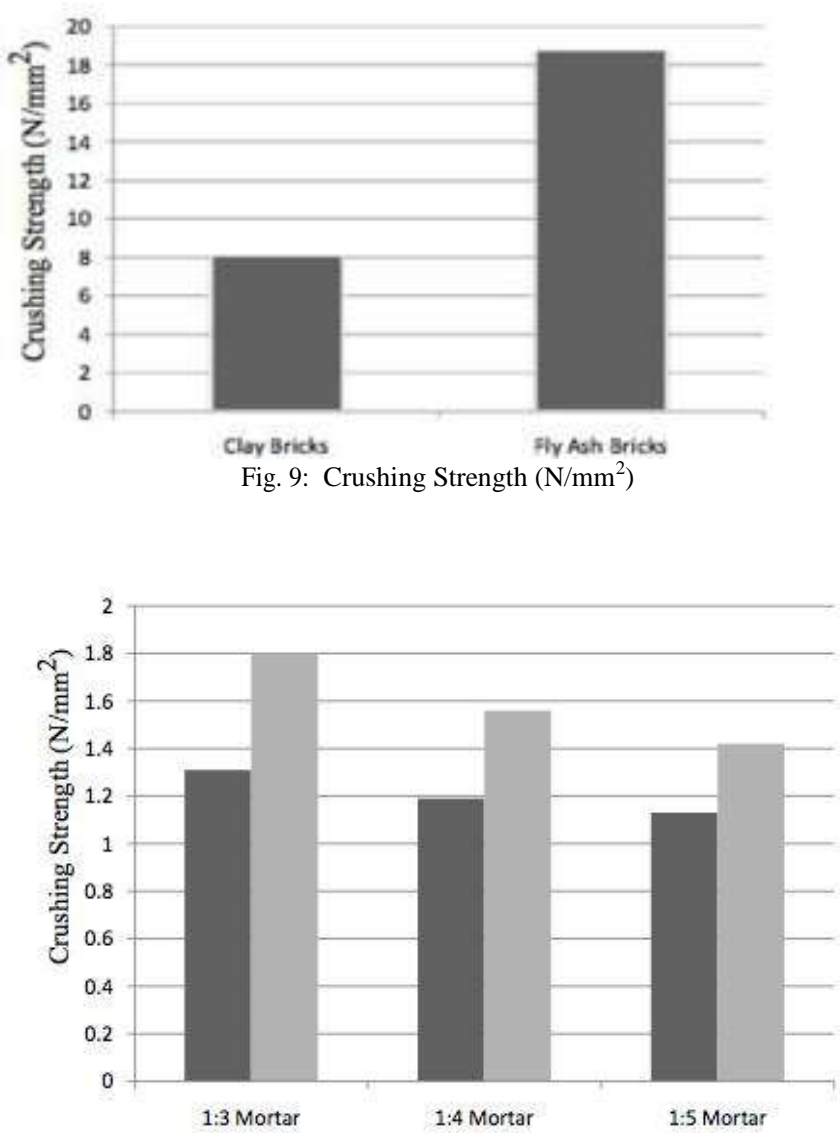

Fig. 10: Crushing Strength by Prisms $\left(\mathrm{N} / \mathrm{mm}^{2}\right)$

\section{Clay Bricks}

\section{Fly Ash Bricks}

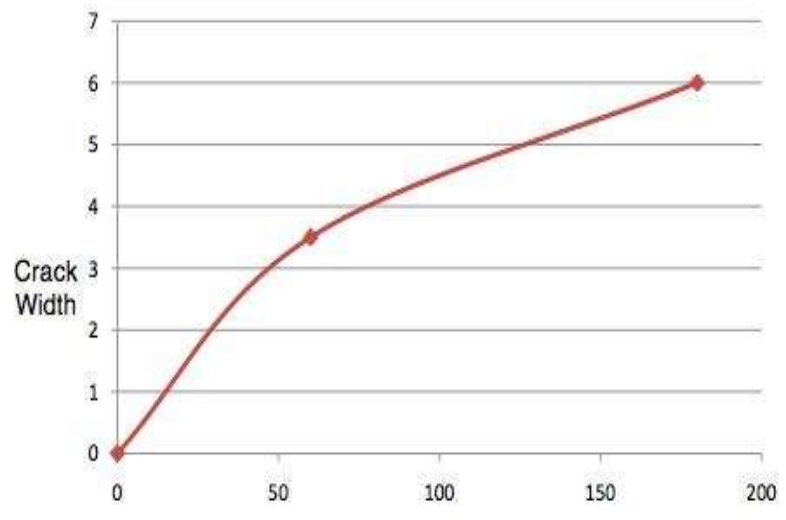

Fig. 11: Cracks in 1: 5 Cement Sand Mortar Prism

In prism testing of 1:5 cement sand mortar maximum width of crack appeared to be $3.5 \mathrm{~mm}$ and average width of crack was 1 $\mathrm{mm}$ on applying load of $60 \mathrm{KN}$. On again applying load crack were measured with the maximum width of $6 \mathrm{~mm}$ and average crack width of $2 \mathrm{~mm}$ by applying load of $180 \mathrm{KN}$.

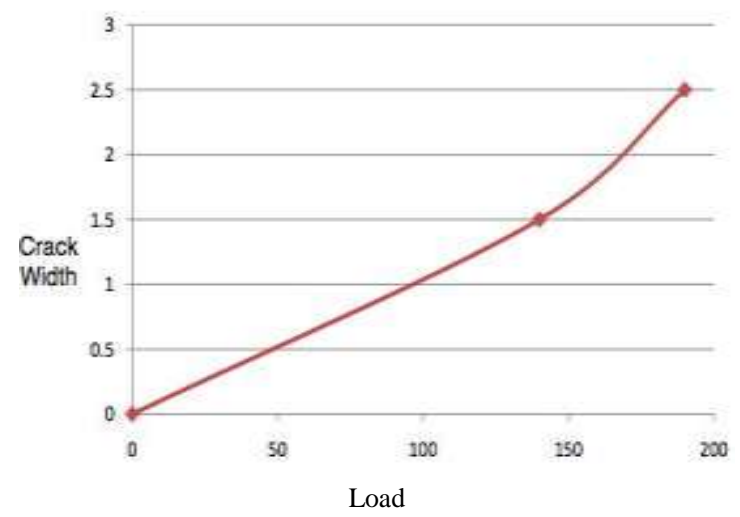

Fig. 12: Cracks in 1:4 Cement Sand Mortar

In prism testing of 1:4 cement sand mortar maximum width of crack appeared to be $1.5 \mathrm{~mm}$ and average width of crack was 1 $\mathrm{mm}$ on applying load of $140 \mathrm{KN}$. On again applying load crack were measured with the maximum width of $2.5 \mathrm{~mm}$ and average crack width of $1.5 \mathrm{~mm}$ by applying load of $190 \mathrm{KN}$.

Prism of 1:4 cement sand mortar failed on applying load of 264 $\mathrm{KN}$

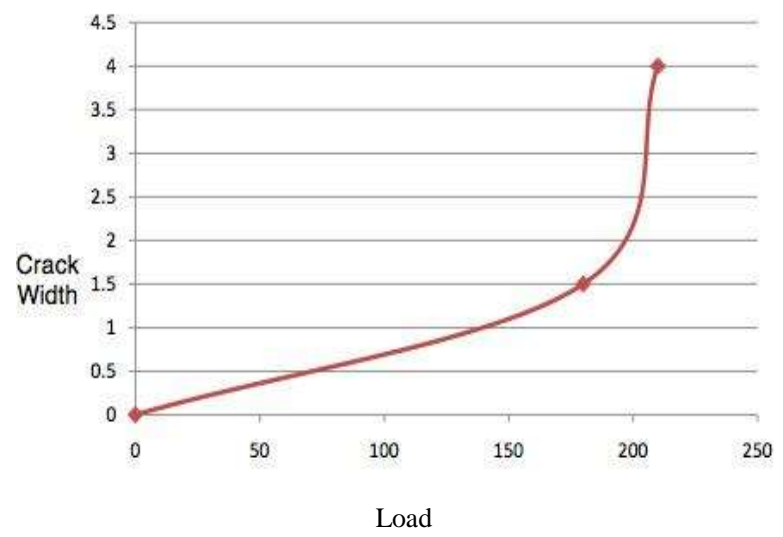

Fig. 13: Cracks in 1:4 Cement Sand Mortar

In prism testing of 1:3 cement sand mortar maximum width of crack appeared to be $3.5 \mathrm{~mm}$ and average width of crack was 1.5 
mm on applying load of $180 \mathrm{KN}$. On again applying load crack were measured with the maximum width of $6 \mathrm{~mm}$ and average crack width of $2 \mathrm{~mm}$ by applying load of $210 \mathrm{KN}$.

Prism of 1:3 cement sand mortar failed on applying load of 290 $\mathrm{KN}$.

\section{CONCLUSION}

a. Fly Ash Bricks were found to be sufficiently hard as scratching by the finger nail on the surface left no impression on it as compared to normal bricks.

b. The Efflorescence of all bricks tested were found to be slight as white or grey deposits were less than $10 \%$ on surface of the bricks which is almost same as that in the normal bricks.

c. A ringing sound in the Fly ash Bricks was observed to be far better than that in normal bricks.

d. Structure of the bricks was found to be compact, homogeneous and free from any defects like holes, lumps etc as compared to normal bricks.

e. The average absorbed moisture content of clay bricks is found to be $11.93 \%$ and for fly ash bricks are found to be $9.77 \%$. Thus there is net $18.10 \%$ decrease in moisture absorbed for fly ash bricks as a part to clay bricks.

f. The crushing strength of clay bricks is found to be 8.14 $\mathrm{N} / \mathrm{mm}^{2}$ and for fly ash bricks is found to be $18.81 \mathrm{~N} / \mathrm{mm}^{2}$. Thus there is net $56.72 \%$ increase is crushing strength for fly ash bricks as a part to clay bricks.

g. The crushing strength by prism of clay bricks is found to be $1.31 \mathrm{~N} / \mathrm{mm}^{2}$ and for fly ash bricks is found to be $1.8 \mathrm{~N} / \mathrm{mm}^{2}$. Thus there is net $27.22 \%$ increase is crushing strength by prism for fly ash bricks as compared to clay bricks.

h. The crushing strength by prism of clay bricks is found to be $1.19 \mathrm{~N} / \mathrm{mm}^{2}$ and for fly ash bricks is found to be 1.56 $\mathrm{N} / \mathrm{mm}^{2}$. Thus there is net $23.71 \%$ increase is crushing strength by prism for fly ash bricks as compared to clay bricks.

i. The crushing strength by prism of clay bricks is found to be $1.21 \mathrm{~N} / \mathrm{mm}^{2}$ and for fly ash bricks is found to be 1.59 $\mathrm{N} / \mathrm{mm}^{2}$. Thus there is net $23.90 \%$ increase is crushing strength by prism for fly ash bricks as compared to clay bricks.

\section{FUTURE EXTENSION}

Instead of Fly Ash, investigations can be done on waste material such as saw dust, lime sludge, rice husk etc. Thermal conductivity can also be investigated for such type of brick. Work can be extended by using Fly Ash. Fly ash bricks can be used partially with clay so that economically fly ash bricks can be better used.
Fly ash bricks can be used partially with rice husk so that bonding with mortar will be stronger. Industrial wastes should be better used in brick making for strengthening purpose and also profitable for cleaning society.

\section{ABBREVIATIONS}

FAB - Fly Ash Bricks

CB - Clay Bricks

FAS - Fertile agriculture soil

CST - Crushing Strength Test

PT - Prism Test

AT - Absorption Test

CSMP - Cement Sand Mortar Prism

\section{REFERENCES}

[1] Dass. Mohan, "New Substitutes of Bricks", Civil Engineering and Construction, June 1992, PP22.

[2] Gupta P. C. and Ray S. C., "Commercialisation of Fly ash", The Indian Concrete Journal vol- 167, now. 1993, PP 554-560.

[3] IS: 1077-1992 Specification for common Burnt Clay Building Bricks (Fifth revision).

[4] IS: 1905-1987 Code of Practice for Structural use of Unreinforced Masonry (Third revision)

[5] IS: 2117-1975 Guide for Manufacture of Hand- Made Common Burnt Clay Building Bricks (Second Revision).

[6] Lal. A. K., "Alternate Building Material for low cost housing, "Civil Engineering and Construction, Aug 1991, PP22.

[7] S.C. Rangwala, Engineering Materials, (Fifteenth Edition), 1991, PP 72 112.

[8] Dr. Durgesh C Rail, "Review of design Codes for Masonry Buildings", Department of Civil Engineering,Indian Institute of Technology, Kanpur.

[9] Sengupta. J, "Availability of Fly ash and its Application in Construction Industry", NBO Journal, Vol. XXXIX, April 1984, PP 17-22. K S Nanjunda Rao, "Structural Masonry: Properties and Behavior",Department of Civil Engineering, Indian Institute of Science ,Banglore Kayali, O. (2005) High Performance Bricks from Fly Ash. Proc. World of Coal Ash, Lexington, Kentucky, USA.

[10] Sarangapani, G., Venkatarama Reddy, B. V. and Jagadish, K. S., Structural characteristics of bricks, mortar and masonry. J. Struct. Eng. (India), 2002, 29.

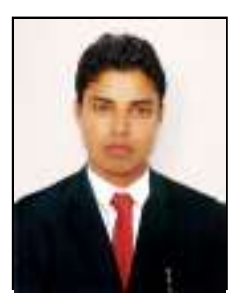

Er. Rinku Kumar, worked as an Assistant Professor in Civil Engineering Department at RPIIT Technical Campus, Bastara, Karnal. Date of Birth: 25th September 1986. I did Master of Technology in Structural Engineering a branch of Civil Engineering from Kurukshetra University, Kurukshetra, India in 2014 and Bachelor of Technology in Civil Engineering from Kurukshetra University, Kurukshetra, in 2011. 